\title{
Relationship between Knowledge and Family Support regarding Hypertension with Blood Pressure Control in Elderly
}

\author{
Iin Kusumawardana'), Didik Tamtomo'), Sugiarto' ${ }^{2)}$ \\ 1) Masters Program in Family Medicine, Sebelas Maret University \\ ${ }^{2)}$ Science of Internal Disease Sub Metabolic Endocrine and Diabetes, \\ Dr. Moewardi Hospital, Surakarta
}

\begin{abstract}
Background: Hypertension is one of the degenerative diseases that have frequently been found among the group of elderly. If hypertension goes uncontrolled, then it might escalate and cause complication. The level of knowledge for both of patients and their families in terms of preventive actions toward hypertension complication is expected to be able to control blood pressure. Among the hypertension patients, the role of family support is very important in order to maintain and to control that the blood pressure will not increase and to return it to the normal state. In relation to this background, the objective in conducting this study was to analyze the relationship between knowledge and family support regarding hypertension with blood pressure control among the elderly with hypertension in the Sangkrah Center of Public Health, City of Surakarta.

Subjects and Method: This was an analytic observational study with cross sectional design. This study was conducted in Sangkrah Community Health Center in the City of Surakarta on November 2016. A total sample of 147 elderly were selected for this study by purposive sampling. The dependent variables in this study was blood pressure and was measured by sphygnomanometer. The independent variables were knowledge and family support and were collected by a set of questionnaire. The data analyzed by logistic regression.

Results: Family knowledge $(\mathrm{OR}=0.38 ; 95 \% \mathrm{CI}=0.13$ to $1.08 ; \mathrm{p}=0.070)$ increased the likelihood of blood pressure control. Elderly who came from family with good knowledge regarding hypertension had 0.4 times better blood pressure control in comparison to those who came from family with poor knowledge regarding hypertension. Family support $(\mathrm{OR}=0.43 ; 95 \% \mathrm{CI}=0.18$ to 1.02; $\mathrm{p}=0.046$ ) increased the likelihood of blood pressure control. Elderly with good family support had 0.4 times better blood pressure than those who had poor family support.

Conclusion: Family knowledge and family support increase the probability of blood pressure control among elderly with hypertension.
\end{abstract}

Keywords: knowledge, family support, blood pressure control, elderly

\section{Correspondence:}

Iin Kusumawardana. Masters Program in Family Medicine, Sebelas Maret University, Jl. Ir. Sutami 36 A, Surakarta 57126, Central Java. Email: iinkusuma9o@gmail.com

\section{BACKGROUND}

Hypertension among elderly is defined as a persistent blood pressure in which the systole pressure is above $160 \mathrm{mmHg}$ and the diastole pressure is equal to $90 \mathrm{mmHg}$ (Sheps, 2005). Hypertension still becomes a health problem among elderly. The results of rapid development nowadays have been able to improve their life expectation rate and, as a result, this increasing life expectation rate is often followed by the increasing degenerative diseases and other health problems among this group of people. Hypertension itself is one of the most frequently found diseases among elderly (Abdullah, 2005). Hypertension can be a serious health problem in the society; if hypertension is not getting controlled, then it will escalate and cause dangerous complications (Gunawan, 2001). 
Indonesian Journal of Medicine (2017), 2(1): 1-9 https://doi.org/10.26911/theijmed.2017.02.01.01

Based on the data of Basic Health Research (Riskesdas, 2013), the prevalence of hypertension in Indonesia has been equal to $26.50 \%$ and the coverage and hypertension diagnosis by medical staff has been equal to $36.80 \%$ or, in other words, most of hypertension cases in the society has not been diagnosed (63.20\%). Furthermore, based on the data of the Office of Health for the Province of Central Java (2014), the number of essential hypertension patients has been 65,525 cases (essential hypertension). These figures show that the pattern of degenerative disease should be given serious attention by all parties. In Sangkrah Health Public Center, essential hypertension occupied the first place from 20 patient visits in 2015 and the number of hypertension patients at that year was 7,759 people.

Both the level of family knowledge and of patient knowledge in terms of taking preventive action toward hypertension complication is expected to control the blood pressure and some of these actions are decreasing the amount of salt consumption, decreasing the amount of fat consumption, performing regular exercise, not smoking and not drinking liquors (Margatan A., 2005).

Among hypertension patients, family support has a very important role in maintaining and controlling the blood pressure and in returning it to the normal state. In addition, blood pressure measurement might also be conducted by the family who has learned about hypertension from medical staff (Awotidebel, 2014).

According to Wijaya (2010), the most important aspects in preventing hypertension among elderly are life style change, low salt diet, body weight loss among people with obesity and life style modification. These aspects should be given top priority as the first step in conducting hypertension medication.

From a preliminary study conducted at the Working Region of Sangkrah Community health center, the researchers found that 1,081 elderly who performed their medical checkup in this community health center on 2015 suffered from hypertension. The habit of these elderly was consuming salty food; if their food was less salty then it would be tasteless and this made the elderly lost their appetite. For them, salty food was tasty and more enjoyable to eat. This habit was also found among all family members. In other words, family support toward the efforts of undergoing low salt diet had been low. This habit and culture of consuming salt becomes one of the obstacles in conducting and complying to the low salt diet among elderly with hypertension.

Looking at the background, the purpose of the study was analyzing the relationship between knowledge regarding hypertension and blood pressure control among elderly with hypertension in Sangkrah Community health center, City of Surakarta.

\section{SUBJECTS AND METHOD}

This study was an observational analytical research with cross sectional design. The researchers had conducted a study in Sangkrah Community health center in the City of Surakarta with the following ethical clearance: 876/ X/ HREC/ 2016. The study was conducted by gathering the primary data through the distribution of a questionnaire regarding hypertension knowledge and family support toward elderly patients who afforded their treatment in Sangkrah Community health center. The total subjects in this study were 147 elderly patients. The population in this study was all elderly with hypertension who visited the community health center. The population of elderly 
with hypertension on 2015 was 1,081 people. The sample was gathered from this population based on the criteria of inclusion and exclusion.

In this study, the researchers implemented purposive sampling technique for gathering the sample (Dahlan M, 2009).

The criteria of inclusion were as follows:

1. Elderly with hypertension who had regular treatment in Sangkrah Community health center within the last three months.

2. Elderly who had been 60 years old and above.

3. Families who approved the inform consent.

On the other hand, the criteria of exclusion were as follows:

1. Elderly with Diabetes mellitus and heart disease.

2. Hypertension patients who had been treated with the same single medication (Captopril).

Then, the number of sample in this study was attained by using the calculation formula of cross-sectional study as follows (Murti B, 2013):

$$
\begin{aligned}
& \mathrm{n}=\underline{\mathrm{Z}}_{\frac{1-\alpha / 2}{2} \cdot \mathrm{p} . \mathrm{q}}^{\mathrm{d}^{2}} \\
& \mathrm{n}=\frac{(1.96)^{2} \cdot 0.09 \cdot 0.91}{0.05^{2}}
\end{aligned}
$$$$
\mathrm{n}=125
$$

In order to avoid dropout, the researchers added $10.00 \%$ sample more so that the total sample became 138 people.

Note:

$$
\begin{aligned}
\mathrm{n}= & \text { sample size } \\
\mathrm{p}= & \text { prevalence of dependent variable } \\
& \text { on the population }(9.00 \%) \\
\mathrm{q}= & 1-\mathrm{p} \\
\mathrm{Z} 1-\alpha / 2= & \mathrm{Z} \text { statistics, alpha standardized de- } \\
& \text { rivatives } 0.05 \\
= & 1.96
\end{aligned}
$$

$\mathrm{d}=$ delta, absolute precision or margin of errors desired in both sides of propositions (5.00\%)

Based on the calculation above, the researchers attained 138 elderly as the sample size for the study.

Operational Definition

1) Family knowledge regarding hypertension refers to family understanding about what they have learned in relation to hypertension and this includes definition of hypertension, definition of hypertension complication, hypertension complication, signs and symptoms of complications and factors of complication risks.

Measurement: questionnaire with Guttman scale that contains 2 alternatives (true false).

Scale: nominal

Results:

Good knowledge: $60.00 \%$ - 100.00\%

Poor knowledge: $\leq 60.00 \%$

Instrument: knowledge test items-questionnaire.

2) Family support refers to the involvement of a family member (child) in motivating the other family member (elderly) to attend hypertension treatment and medication programs.

a. Emotional Support refers to the support provided by a family in the form of attention, affection and love toward elderly with hypertension. Measurement: questionnaire regarding family emotional support in the form of Likert scale namely always, often, seldom and never with 10 questions.

b. Appreciation Support refers to the support provided by a family in the form of appreciation, listening and conversation that involves elderly. Measurement: questionnaire regarding family emotional support in the form of Likert scale namely always, often, seldom and never with 10 questions. 
c. Informational Support refers to the support provided by a family in the form of information distribution regarding hypertension toward elderly with hypertension. Measurement: questionnaire regarding family information support in the form of Likert scale namely always, often, seldom and never with 14 questions.

d. Instrumental Support refers to the support provided by a family in the form of assistance, efforts, time and cost in controlling the elderly' health. Measurement: questionnaire regarding family instrumental support in the form of Likert scale namely always, often, seldom and never with 10 questions.

Measurement results:

Good $=33-78$

Poor $=18-32$

Scale: nominal

Instrument: questionnaire

3) Blood Pressure Control refers to systole and diastole pressure of elderly with hypertension, usually $\leq 150 / 90 \mathrm{mmHg}$.

Measurement: sphygnomanometer operation

Scale: nominal

Table 1. Measurement results

\begin{tabular}{lcl}
\hline Classification & $\begin{array}{c}\text { Systole } \\
\text { Pressure } \\
(\mathrm{mmHg})\end{array}$ & $\begin{array}{l}\text { Diastole } \\
\text { Pressure } \\
(\mathrm{mmHg})\end{array}$ \\
\hline Controlled & $130-140$ & 90 \\
Uncontrolled & $150-160$ & $90-100$ \\
\hline
\end{tabular}

The instruments that the researchers implemented in the study were questionnaire and sphygnomanometer. The questionnaire was distributed in order to gather the data on respondents' characteristics, respondents' knowledge in relation to hypertension and family support.

For the respondents' identity, the data that the researchers gathered were name, sex, age, education and occupation. The data regarding hypertension would be elaborated as follows.

a. Research instrument for measuring knowledge regarding hypertension

Knowledge

- Definition of hypertension : 1,2

- Definition of complication hypertension : 3

- Hypertension complication : 5, 6

- Signs and symptoms of complication : 8 , 9, 10

- Signs and symptoms of hypertension : 11, 12

- Factors of complication risks : 13, 14, 15, 1617,18

Results:

Good knowledge: $60 \%-100 \%$

Poor knowledge: $\leq 60$

b. Questionnaire of family support assessment

The questionnaire that had been distributed in order to assess the family support in this study was modified from the questionnaire developed by Yenni (2011) regarding the relationship between family support and behaviors of elderly with hypertension in controlling their health. The questionnaire in this study involved 36 questions in relation to the family and these questions included emotional support, appreciative support, informational support and instrumental support. The form of statement that had been used was Likert scale with positive and negative statements.

Every question had four alternatives with following criteria: $3=$ always, $2=$ often, $1=$ sometimes and $\mathrm{o}=$ never for the positive statements and $\mathrm{O}=$ never, $1=$ often, $2=$ sometimes and $3=$ never for the negative statements. Respondents answered one of the alternatives by putting $(\sqrt{ })$ on the available columns.

1) Emotional support 
Emotional support had 8 statements. The positive statements were provided in the statement number 1, 2, 3, 4, 5, 7 and 8. On the contrary, the negative statement was found in the statement number 6 .

2) Appreciative support

Appreciative support had 8 statements. The positive statements were provided in the statement number 10, 11, 12, 14 and 15. On the contrary, the negative statements were provided in the statement number 9,13 and 16.

3) Informational support

Informational support had 13 statements and all of these statements were positive. These positive statements were provided from number 17 until 29.

4) Instrumental support

Instrumental support had 7 statements. The positive statements were provided in the statement number 30, 31, 32, 34, 35 and 36 . On the contrary, the negative statement was provided in the statement number 33 .

Instrument test was conducted by the researchers toward 40 respondents who were in Sangkrah Community health center. From the results of validity test for the questionnaire of knowledge questions, the researcher found that 6 of 18 statements had r-count that had been smaller than $\mathrm{r}$ table $(\mathrm{r}=0.31)$, namely the statement number 3, 4, 6, 9, 10 and 14 (attached). Thereby, the researchers might conclude that from 18 statements there had been 12 valid statements and the remaining 6 statements that had been invalid were eliminated. These valid statements then would be sent into reliability test. The results of reliability test showed $\mathrm{r}$ alpha $=0.60$. These results implied that the statements had been reliable bcause $r$ alpha $>r$ table.

In the results of validity test for the questionnaire of family support test items, the researchers found that 8 of 36 state- ments had $\mathrm{r}$ count that had been smaller than $\mathrm{r}$ table $(\mathrm{r}=0.31)$ namely the statement number $1,10,11,14,18,26,30$ and 36 (attached).Therefore, the researchers might conclude that from 36 statements there had been 28 valid statements and the remaining 8 statements that had been invalid were eliminated. These valid statements then were sent into reliability test. The results of reliability test showed $\mathrm{r}$ alpha $=0.70$. These results implied that these statements had been reliable because $\mathrm{r}$ alpha $>\mathrm{r}$ table.

The bivariate and multivariate data analysis was conducted in order to identify the inter-relationship variable by means of statistical test. The statistical tests that would be implemented were Chi Square with rate of significance $95 \%$ and a 0.05 , mean and logistic regression model significance test. This logistic regression model was implemented because the data that had been attained were categorical. The analysis toward the data that had been gathered would be processed by SPSS (Statistical Program for Social Science) version 16.0 for Windows.

Ninetytwo respondents (62.60\%) were female, while the remaining 55 respondents (37.40\%) were male; in other words, most of the respondents in this study were female. Then, 147 respondents (100.00\%) were categorized into the early elderly. 92 respondents (62.60\%) had high educational level, while the remaining 55 respondents (37.40\%) had low educational level. 126 respondents $(85.70 \%)$ had families with good background knowledge of hypertension, while the remaining 21 respondents (14.30\%) had families with poor background knowledge of hypertension.

Furthermore, 90 respondents (61. 20\%) had good family support, while the remaining 57 respondents (38.80\%) had poor family support. Last but not the least, 120 respondents $(81.60 \%)$ had uncontroll- 
Indonesian Journal of Medicine (2017), 2(1): 1-9 https://doi.org/10.26911/theijmed.2017.02.01.01

ed blood pressure while the remaining 27 respondents (18.40\%) had controlled blood pressure.

\section{RESULTS}

\section{Bivariate Analysis}

Table 2. Relationship between family knowledge regarding hypertension and blood pressure on elderly patients with hypertension

\begin{tabular}{lrrrr}
\hline \multirow{2}{*}{ Knowledge } & \multicolumn{2}{c}{ Blood pressure } & \multirow{2}{*}{ Total } & p \\
\cline { 2 - 3 } & High & Low & & \\
\hline Good & 106 & 20 & 126 & \\
Poor & 14 & 7 & 21 & 0.056 \\
Total & 120 & 27 & 147 & \\
\hline
\end{tabular}

From the table, the researchers might view the results of statistical tests carried out by Chi Square test with SPSS 16 program. From these results, the researchers find that the significance probability value or $\mathrm{p}$ $=0.056$. Because $\mathrm{p}>0.05$, the researchers conclude that they do not find any relationship between knowledge level regarding hypertension and elderly' blood pressure.

Table 3. Relationship between family support and blood pressure among eldely patients with hypertension

\begin{tabular}{lrrrc}
\hline \multicolumn{1}{c}{ Family } & \multicolumn{2}{c}{ Blood pressure } & \multirow{2}{*}{ Total } & \multirow{2}{*}{ p } \\
Support & High & \multicolumn{1}{c}{ Low } & & \\
\hline Good & 78 & 12 & 90 & \\
Poor & 42 & 15 & 57 & 0.048 \\
Total & 120 & 27 & 147 & \\
\hline
\end{tabular}

From the above table, the researchers might view the results of statistical tests by SPSS 16 and the researchers find that the significance probability value or $\mathrm{p}=0.048$. Because $\mathrm{p}<0.05$, the researchers conclude that they find a relationship between family support and elderly patients' blood pressure.

\section{Multivariate Analysis}

The blood pressure of elderly patients who come from the family with good knowledge is approximately 0.3 times better than that of elderly patients who come from family with poor knowledge and there is not any significant relationship between family knowledge and blood pressure of elderly patients with hypertension (OR $=0.38 ; 95 \%$ $\mathrm{CI}=0.13$ to $1.08 ; \mathrm{p}=0.070$ ).

Table 4. Relationship between family knowledge regarding hypertension and family support regarding blood pressure among elderly patients with hypertension

\begin{tabular}{|c|c|c|c|c|}
\hline \multirow[b]{2}{*}{ Variable } & \multirow{2}{*}{$\begin{array}{c}\text { OR / } \\
\operatorname{Exp}(\mathrm{B})\end{array}$} & \multirow[b]{2}{*}{ p } & \multicolumn{2}{|c|}{$95 \% \mathrm{CI}$} \\
\hline & & & $\begin{array}{c}\text { Upper } \\
\text { limit }\end{array}$ & $\begin{array}{c}\text { Lower } \\
\text { limit }\end{array}$ \\
\hline Knowledge & 0.38 & 0.070 & 0.13 & 1.08 \\
\hline Family & & & & \\
\hline $\begin{array}{l}\text { support } \\
\text { Constant }\end{array}$ & $\begin{array}{l}0.43 \\
0.64\end{array}$ & $\begin{array}{l}0.046 \\
0.784\end{array}$ & 0.18 & 1.02 \\
\hline
\end{tabular}

Then, the blood pressure of elderly patients who have good family support is approxymately 0.4 better than that of elderly patients who have poor family support and there is a significant relationship between family support and blood pressure of elderly patients with hypertension (OR= $0.43 ; 95 \% \mathrm{CI}=0.18$ to $1.02 ; \mathrm{p}=0.046$ ).

\section{DISCUSSION}

This study was conducted with measurement toward family knowledge level regarding hypertension and family support toward 147 respondents. From the results of the study, the researchers found that 126 respondents (85.70\%) had family with good knowledge. Such good knowledge that the family of these respondents had were attained by multiple information regarding definition, causing factors, symptoms, complication and hypertension preventive efforts. They found these aspects from medical staff, other people and surrounding environment. The knowledge itself might also be attained through the facts that they read or they listened to from communication medium such as newspaper, magazines, television, radio and alike.

Based on the data analysis by Chi Squarewith $\mathrm{p}=0.056$, the researchers found that there was not any relationship between 
parents' knowledge level regarding hypertension and elderly blood pressure. The reason might be that poor knowledge background and habit would be followed by poor action in preventing the occurrence of hypertension among the family members.

Knowledge has been an important domain in establishing overt behavior of an individual. Based on results of studies and experiences, behavior that has been based on knowledge will last longer than the one that has not been based on knowledge.

This study is not in line with that of Nugraha (2014), which states that there is a relationship between family knowledge leveland complication preventing acts among hypertension patients. This difference might be caused by the fact that the sample in the study by Nugraha has been hypertension patients instead of elderly with hypertension.

In the same time, this study is also not in line with that of Godfrey, Iyalomhe \& Sarah (2010) which states that hypertension is related to knowledge, attitude, and lifestyle among the patients.

Most experts state that knowledge and attitude provide less support toward the prevention of hypertension. If an individual has good knowledge regarding health, then the individual will try avoiding or minimizing anything that might cause a disease. At least the individual will try displaying supporting behavior in order to improve the degree of his or her personal health.

Based on the data analysis toward family support, the researcher found that 90 (61.20\%) elderly patients had good family support. The results of Chi Square test with $\mathrm{p}=0.048$ showed that there was a relationship between family support and elderly patients' blood pressure control. Similarly to the results of a study by Zulfitri (2006), this study found a relationship between family support and behaviors of elderly patients with hypertension in controlling their health so that elderly patients with hypertension had good behaviors in maintaining their health and they were expected not to suffer from worse condition. The results of this study were also similar to those by Setyaningrum (2009) which stated that 17 (51.50\%) respondents had moderate family support. The researchers found that most of the family members only provided general suggestion toward the respondents without providing any responsive feedback in order to solve the problems that the respondents had.

Setiadi (2008) stated that family support consists of instrumental support, informational support, appreciative support and emotional support. These components might support the respondents in improving their health. Family support might decrease mortality so that the patients will be easier to recover themselves from their disease and to improve their emotional health. The positive influence of family support might become an adjustment toward the events in their stressful life (Setiadi, 2008).

As having been stated by Friedman, Bowden and Jones (2003), family support has been the most significant source of assistance for family members. Based on that statement, the researchers might state that elderly with hypertension who have good family support will also display good behaviors in maintaining their health. This statement is also supported by McMurray (2003), who stated that family support belongs to the strengthening factors that might influence the lifestyle and the behavior of an individual so that these factors might impact the quality of his or her life and health.

Family role is also expected to be able to provide support and motivation toward 
hypertension patients in optimizing their life such as consuming healthy food, performing diet and routinely checking blood pressure. 120 (81.60\%) elderly patients had uncontrolled blood pressure, while the remaining 27 (18.40\%) elderly patients had controlled blood pressure. The older an individual, the higher his or her pressure will be; therefore, elderly people tend to have higher blood pressure than younger people.

When the researchers performed the blood pressure measurement, the respondents displayed various conditions; some of them were relaxed and the others had just finished their activities since they were sweating. However, the remaining respondents seemed to be anxious. In addition to hypertension, these various conditions also influence the results of blood pressure measurement.

Most of the respondents suffered from hypertension for 5 to 10 years. This means that most of the respondents have been aware to afford the treatment in the community health center. Some people do not care about their hypertension and they consider that high blood pressure is just common. When an individual has been diagnosed having hypertension, he or she should drink the medicine for the rest of his or her life and they should regularly check up their health every ten days in a row. The respondents who have been suffering from hypertension for 5 until 10 years are the ones who have been aware that hypertension should not be ignored; therefore, they have medical checkup in this community health center in order to attain information regarding hypertension from medical staff.

The difficulty in conducting this study is that not all respondents are able to read and write so that they should be accompanied when they complete the questionnaire that has been provided by the researchers.
Based on the results and the discussions, the researchers might conclude that:

1. There is not any significant relationship between family knowledge regarding hypertension and blood pressure of elderly patients with hypertension.

2. There is significant relationship between family support and blood pressure of elderly patients with hypertension.

3. There is an insignificant relationship between family knowledge regarding hypertension and blood pressure of elderly patients' with hypertension and there is a more significant relationship between family support and blood pressure of elderly patients with hypertension.

\section{REFERENCE}

Abdullah, Masqon (2005). Kejadian Penyakit Jantung di Indonesia, http://www. fkm.undip.ac.id/data/index.php?actio $\mathrm{n}=\& \mathrm{idx}=2701$, diakses 20 Juli 2016

Awotidebel TO, Adedoyini RA (2014). Knowledge, attitude and Practice of Exercise for blood pressure control: A cross-sectional survey. Department of Medical Rehabilitation, College of Health Sciences, Obafemi Awolowo University, Journal of Exercise Science andPhysiotherapy 10(1): 1-10.

Badan Penelitian dan Pengembangan Kesehatan Kementrian Kesehatan RI. (2013). Riset Kesehatan Dasar (Riskesdas) 2013. Jakarta.

Dahlan M (2009). Besar Sampel dan Cara Pengambilan Sampel dalam Penelitian Kedokteran dan Kesehatan. Jakarta: Salemba Medika.

Dinkes Kota Surakarta (2014). Profil Kesehatan Kota Surakarta tahun 2014. Dinas kesehatan Kota Surakarta.

Friedman MM, Bowden JEG (2003). Family Nursing: Research, theory and Practise Fifth edition. New Jersey: Prentice Hall. 
Godfrey BS, Iyalomhei, Sarah I (2010). Hypertension-related Knowledge, Attitudes and Life-Style Practices among hypertensive patients in a Sub-Urban Nigerian Community. Journal of Public Health and Epidemiology 2(4): 7177.

Gottlieb BH (2003). Social Support Strategies (Guidelines for Mental Health Practise). California: Sage Publication.

Gunawan L (2001). Hipertensi Tekanan Darah Tinggi. Yogyakarta: Kanisius

Kuntjoro (2002). Dukungan Sosial pada Lansia.http://www.epsikologi.com/us ia/Jakarta. Diakses 7 Mei 2016

Margatan A (2005). Kiat Hidup Sehat Bagi Lanjut Usia. Rineka Cipta: Solo.

McMurray A (2003). Community health and wellness: A sociological Approach. Philadelpia: Mosby

Murti B (2013). Desain dan Ukuran Sampel Untuk Penelitian Kuantitatif dan Kualitatif di Bidang Kesehatan. Yogyakarta: Gajah Mada University Press

Notoatmodjo S (2007). Promosi Kesehatan dan Ilmu Perilaku. Jakarta: Rineka Cipta

Nugraha BK (2014). Hubungan Tingkat Pengetahuan Keluarga dengan Sikap Pencegahan Komplikasi pada Pasien Hipertensi di Wilayah Kerja Puskesmas Sangkrah Surakarta. Skripsi. Universitas Muhammadiyah Surakarta.
Sheps, Sheldon G (2005). Mayo Clinic Hipertensi, Mengatasi Tekanan Darah Tinggi. Jakarta: PT Intisari Mediatama.

Setiadi (2008). Konsep dan Keperawatan Keluarga. Yogyakarta: Graha Ilmu.

Setyaningrum D (2009). Hubungan Dukungan Sosial Keluarga Dengan Kepatuhan Menjalani Terapi Hemodialisa Pada Pasien Gagal Ginjal Kronik di Unit Hemodialisa RS PKU Muhammadiyah. Program studi ilmu keperawatan. STIKES Aisyah Yogyakarta

Wijaya R (2010). Pada Usia Lanjut Tekanan Darah Harus Terkontrol://http.www. dradio1034fm.or.id. diakses 20 April 2016

Yenni (2011). Tesis Hubungan Dukungan Keluarga dan Karakteristik Lansia dengan Kejadian Stroke pada Lansia Hipertensi di Wilayah Kerja Puskesmas Perkotaan Bukittinggi. UI.

Zulfitri R (2006). Hubungan Dukungan Keluarga dengan Perilaku Lanjut Usia Hipertensi dalam mengontrol Kesehatannya di Wilayah kerja Puskesmas Melur Pekanbaru. Tesis FIK UI Jakarta. 